\begin{tabular}{|c|c|c|c|c|}
\hline 20 & $\begin{array}{l}\text { Staple diet } \\
\text { Funding reprieve for } \\
\text { traditional approach } \\
\text { to breeding wheat } \\
\text { p790 }\end{array}$ & $\begin{array}{l}\text { All together now } \\
\text { sARS encourages } \\
\text { international } \\
\text { collaborations } \\
\text { p791 }\end{array}$ & $\begin{array}{l}\text { Delta blues } \\
\text { Ecologists fear for } \\
\text { the future of the } \\
\text { Colorado River } \\
\text { p793 }\end{array}$ & $\begin{array}{l}\text { Green shoots } \\
\text { Physics lab lends } \\
\text { Hulk a helping } \\
\text { hand } \\
\text { p794 }\end{array}$ \\
\hline
\end{tabular}

\title{
US army attacked over published patent for 'bioweapons grenade'
}

\section{Erika Check, Washington}

Critics are charging that a patent granted to the US army raises troubling questions about the way the military handles information on biological and chemical weapons.

The patent, issued in February, is for a "rifle-launched non-lethal cargo dispenser" that can be filled with "smoke, crowd control agents, biological agents, chemical agents, obscurants, marking agents, dyes and inks, chaffs and flakes" (N. Gonzalez et al. US patent $6,523,478 ; 2003)$. It goes on to describe in detail how to make the projectile.

Greg Aharonian, a patent consultant based in San Francisco, says that the patent constitutes step-by-step instructions for making a lethal weapon. "It is hypocritical to complain about countries developing biological and chemical weapons when we are openly educating them on how to do so," he says.

Other observers doubt whether the patent is a real security risk. "I don't think this would be a particularly effective munition for delivering biological agents, so I don't see its publication as a security issue," says Mark Wheelis, a microbiologist at the University of California, Davis, who advises the Federation of American Scientists on bioweapons issues.

But Wheelis and others are still concerned that the patent's claims made it through the Department of Defense's internal review process. The Pentagon reviews its inventions to see if publishing patents on them could threaten national security, and it seals potentially threatening ones behind secrecy orders.

The critics say that the reviewers should have known that the United States is banned from producing biological weapons, both by the Biological Weapons Convention and by federal law. "The army needs to assure the country and the international community that everybody who reviews these projects is familiar with the obligations of international and domestic law," says Wheelis.

Miguel Morales, a spokesman for the army's Edgewood Chemical Biological Center in Aberdeen, Maryland, says that the army has no intention of using the patented grenade as a biological or chemical weapon. He says that reference to biological and

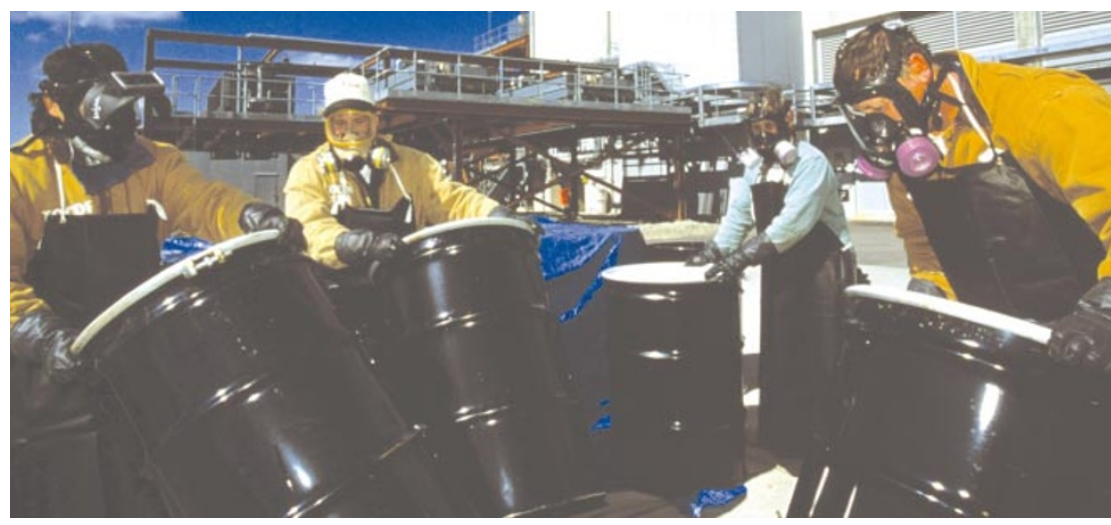

The US is destroying its chemical weapons stockpile, but is its research breaking international rules?

chemical agents was inserted by a lawyer who was trying to cover as much ground as possible with the patent - a common practice in intellectual property filings.

"We're not violating any treaty, and we're going to be deleting those words in the patent to ensure that there is no further misunderstanding," Morales says.

But the critics contend that deleting the troublesome words from the patent does not answer the larger question of why they were written into the application in the first place.

"To have that description openly in the application reveals some major problems in the way the United States thinks about that particular weapons system - and how it's thinking about the larger question of biological and chemical agents," says David Fidler, an international lawyer at Indiana University in Bloomington.

\section{Whaling group backs conservation}

Charlotte Westney

The International Whaling Commission (IWC) has voted in favour of a fundamental shift in its remit, formally recognizing for the first time that conservation is part of its job.

The decision, carried by 25 votes to 20 , was made on 16 June at the commission's 55th annual meeting, held in Berlin. Members agreed to set up a conservation committee within the IWC, which will examine the effect of whaling and other activities, such as commercial fishing, on a broad range of cetacean species. Until now, the IWC primarily considered how to manage the whaling industry.

But the vote leaves a deep rift in the commission. Countries that support commercial whaling, such as Japan, Norway and Iceland, all said that they will not participate in or fund the new committee. Minoru Morimoto, Japan's commissioner at the IWC, said that the decision to protect all whales irrespective of conservation status undermined more than ten years of work by the IWC's scientific committee into sustainable commercial whaling.

The vote was enthusiastically received by more than 40 conservation groups that supported it. They hope that the committee will address issues such as the 300,000 whales, dolphins and porpoises that are killed each year when they become entangled in fishing nets. "This is a historic day for cetacean conservation," says Susan Lieberman, who led a delegation at the IWC talks sent by the environmental organization the WWF. 